\title{
DINAMIKA RESILIENSI REMAJA YANG PERNAH MENGALAMI KEKERASAN ORANG TUA
}

\author{
Ratih Ambarwati \\ Pihasniwati \\ Program Studi Psikologi Fakultas Ilmu Sosial dan Humaniora \\ Universitas Islam Negeri Sunan Kalijaga Yogyakarta
}

\section{INTISARI}

Penelitian ini bertujuan untuk menggambarkan dinamika resiliensi remaja yang pernah mengalami kekerasan orang tua, menjelaskan faktor-faktor yang melatarbelakangi terbentuknya resiliensi tersebut, serta mengetahui dampak yang muncul akibat dari tindak kekerasan yang dialami. Penelitian ini menggunakan metode kualitatif dengan jenis penelitian fenomenologi. Subjek yang digunakan dalam penelitian ini sebanyak tiga orang dengan kriteria remaja yang berusia 13 sampai 19 tahun, laki-laki atau perempuan, dan bersedia menjadi subjek penelitian.

Penelitian ini menunjukkan bahwa remaja yang pernah menjadi korban kekerasan orang tua bisa bangkit dari keterpurukannya di masa lalu dan hal tersebut dipengaruhi oleh faktor protektif dan faktor resiko. Faktor protektif berupa karakteristik individu yang kuat dan mau untuk berubah, relasi dan dukungan sosial yang diperoleh, adanya kegiatan bermanfaat yang dilakukan, suasana kehidupan yang berbeda \& lebih nyaman, memiliki minat \& bakat, serta memiliki kapasitas untuk belajar. Faktor resiko remaja untuk bisa resiliensi diantaranya kurang adanya kemampuan untuk menjalin hubungan yang baik dengan pelaku kekerasan, belum adanya pemaafan, dan masih ada ketergantungan terhadap masa lalu yang menyakitkan seperti marah, sedih, dan takut ketika teringat tentang kejadian kekerasan yang pernah dialami.

Remaja memiliki resiliensi yang terwujud dalam beberapa aspek yaitu remaja memiliki nilai positif dan penilaian yang baik terhadap kehidupan saat ini, perubahan fisik yang lebih baik, memiliki harapan dan bertanggung jawab terhadap kehidupannya sendiri, independent, optimis, memiliki kemampuan dalam memecahkan masalah, memiliki impuls kontrol dan efikasi diri, bisa mengambil pelajaran dari kehidupan, realistis terhadap hal-hal baik yang bisa dilakukan, serta memliki rasa syukur.

Kata kunci : resiliensi, remaja, kekerasan orang tua 


\title{
DYNAMICS OF TEENAGER'S RESILIENCE WHO HAVE EXPERIENCED VIOLENCED FROM PARENTS
}

\begin{abstract}
This study aims to describe the dynamics of teenagers' resilience who have experienced violent from parents, explain the factors that are the background of the formation of resilience, as well as knowing the impacts arising out of the acts of violence that being experienced. This study uses qualitative method with phenomenology type of research. The subject uses in this research are three people with criteria teenagers aged 13 to 19 years old, male or female, and are willing to be the subject of the study.

The study shows that teenagers who had been the victims of violence parents can rise from their deterioration of the past and it is influenced by several factors, namely protective factor and risk factor. Protective factors or the supporting factors are the individual characteristics that are strong and willing to change, relationship and social support that is obtained, the presence of useful activities performed, a different \& more comfortable life's atmosphere, has an interest \& talent, as well as has the capacity to learn. Risk factors or the factors that restrict teenagers from resiliencing are lack of the ability to establish good relationships with the perpetrators of the violence, unable to forgive, and the dependency against the bad past like mad, sad, and scared when reminded of the violence that ever experienced.

The aspect of resilience that appear on teenagers as the victims of violence parents i.e. teenagers have positive values and good judgment on current life, better physical changes, have hope and responsible for the life of their own, independent, optimistic, can make a solution to a problem, have impuls control and self-efficacy, can take lessons from life, realistic towards good things that can be done, as well as having an abundance of gratitude.
\end{abstract}

Key words: resilience, teenagers, violence of parents 
PENDAHULUAN

$\mathrm{K}$

ekerasan terhadap anak \& remaja sudah menjadi

terjadi di berbagai negara termasuk Indonesia (Suyanto,2013). Menurut data dari Komisi Perlindungan Anak Indonesia, terdapat peningkatan angka kekerasan selama 4 tahun terakhir yaitu pada tahun 2011 terjadi 2178 kasus kekerasan, tahun 2012 terjadi 3512 kasus kekerasan, tahun 2013 terjadi 4311 kasus kekerasan, dan pada tahun 2014 terjadi 5066 kasus kekerasan (http://www.kpai.go). Berdasarkan data Jaringan Penanganan Korban Kekerasan Berbasis Gender Kota Yogyakarta sepanjang tahun 2015, jumlah kasus kekerasan fisik maupun psikis terhadap anak \& remaja sudah mencapai 690 kasus danjumlah kasus kekerasan seDIY pada tahun 2015 sudah terakumulasi menjadi lebih dari 2.000 kasus. Data kasus Kekerasan Dalam Rumah Tangga (KDRT) yang dialami oleh anak-anak \& remaja tahun 2015 dilaporkan sebanyak 626 kasus, yakni usia 0-17 berjumlah 86 kasus dan usia di atas 18 tahun sejumlah 540 kasus

(http://www.jogja.tribunnews.com).

Ruang kekerasan terhadap anak sebagian besar terjadi di rumah (129 kasus), di jalanan (79 kasus), di sekolah (10 kasus), di lembaga keagamaan (2 kasus), di sektor perekonomian (21 kasus) (Huraerah, 2012). Berdasarkan data yang diperoleh oleh Komisi Perlindungan Anak
Indonesia dari hasil monitoring dan evaluasi di 9 provinsi, $91 \%$ anak menjadi korban kekerasan di lingkungan keluarga, $87,6 \%$ di lingkungan sekolah, dan 17,9\% di lingkungan masyarakat (http//www.kpai.go). Menurut Yayasan Kesejahteraan Anak Indonesia, kekerasan pada anak yang terjadi didalam rumah sebanyak 48,7\%, di sekolah sebanyak $4,6 \%$, di tempat umum sebanyak 6,1\%, di tempat kerja sebanyak 3,0\%, dan di tempat lainnya sebanyak 37,6\% (Wilis, 2008).

Data yang terdapat pada beberapa sumber tersebut menunjukkan bahwa kekerasan di dalam lingkungan keluarga lebih banyak terjadi dibandingkan dengan lingkungan sekolah maupun masyarakat. Kekerasan terhadap anak \& remaja di dalam lingkungan keluarga tersebut selalu berdampingan pula dengan perilaku pengabaian yang dilakukan oleh orangorang yang penting dalam kehidupan anak \& remaja yang dalam hal ini adalah orang tua. Hal ini menunjukkan bahwa keluarga sudah tidak bisa lagi menjadi tempat untuk memberikan rasa aman terhadap anak \& remaja. Anak \& remaja akan cenderung mengembangkan konsep penolakan dan penerimaan yang diperoleh dari orang tuanya. Penolakan dan penerimaan orang tua membentuk dimensi kehangatan dalam pengasuhan yaitu suatu kualitas ikatan afeksi antara orang tua dan anak (Rohner dalam Schwartz et al, 2009 dalam Lestari, 2012). 
Menurut penelitian yang dilakukan oleh Margaretha (2013), kekerasan biasanya bersifat turun temurun karena anak-anak akan belajar dari orang tuanya tentang bagaimana cara berhadapan dengan lingkungan. Pengalaman menyaksikan atau mengalami langsung kekerasan akan membuat anak-anak membenarkan tindak kekerasan. Korban maupun pelaku kekerasan mengalami trauma kekerasan yang pernah dialami pada masa lalunya. Korban maupun pelaku kekerasan terjerat dalam rantai kekerasan karena mengalami trauma pada masa lalunya sehingga mengembangkan persepsi yang salah tentang kekerasan yang pada akhirnya mempengaruhi ketidakmampuan dalam hal menghadapi permasalahan-permasalahan pribadi individu di masa depan.

Setiap tindak kekerasan yang diterima oleh remaja tentu memiliki dampak-dampak yang merugikan individu secara fisik, psikologis, sosial, dan akademis. Terdapat salah satu aspek perkembangan psikososial yang penting untuk dimiliki remaja agar bisa bangkit menghadapi pengalaman yang menyakitkan, yaitu perkembangan resiliensi. Perkembangan resiliensi penting untuk dicapai karena pada fase remaja banyak terjadi perubahan fisik, psikis, dan sosial. Menurut Santrock (dalam Mulia, 2014), perubahanperubahan ini menuntut individu untuk bisa menjadi dewasa seperti apa yang diharapkan oleh lingkungan. Perubahanperubahan tersebut tidak jarang menimbulkan masalah bagi remaja yang tidak mampu beradaptasi, terlebih juga dipengaruhi oleh kondisi emosi remaja yang masih labil.

Remaja yang tidak mampu untuk beradaptasi akan menyebabkan munculnya perilaku-perilaku maladaptif yang bisa dilakukan oleh remaja yang tentunya membahayakan diri sendiri dan orang lain. Menurut Taufiq (2014), resiliensi atau daya lentur adalah proses kemampuan psikologis individu dalam berespon terhadap stressor kehidupan. Ketika individu memiliki sikap resilien, maka individu tersebut bisa untuk mengatasi berbagai stressor yang ada di kehidupan dan menjadi terbiasa hidup dalam berbagai tekanan yang ada. Resiliensi dibutuhkan oleh remaja karena resiliensi dianggap sebagai kekuatan dasar yang menjadi fondasi dari semua karakter positif dalam membangun kekuatan emosional dan psikologikal seseorang (Desmita, 2008).

Aspek-aspek Resiliensi menurut Reivich \& Shatte (2002) yaitu, Emotional Awareness and Regulation yang berkaitan dengan kemampuan untuk mengendalikan emosi dan tetap tenang di bawah kondisi yang menekan. Selanjutnya yaitu Impulse Control yang berkaitan dengan kemampuan individu untuk mengendalikan keinginan, dorongan, serta tekanan yang muncul dari dalam diri 
seseorang, Realistis Opimism and Thinking

Style yang berkaitan dengan bagaimana cara individu untuk mempercayai bahwa segala hal dalam kehidupan individu bisa berubah kearah yang lebih baik, dan Flexible Thinking of Problem Solve yang berkaitan dengan kemampuan dalam mengidentifikasi penyebab dari permasalahan secara akurat. Selain itu ada Self-Efficacy and Self-Accountability yaitu percaya terhadap kemampuan yang dimiliki dalam memilih dan memutuskan sesuatu, serta bertanggung jawab terhadap hal yang dipilih tersebut. Emphaty berarti individu memiliki kemampuan untuk memahami situasi dari perspektif orang lain. Reaching Out adalah kemampuan individu dalam meraih aspek positif serta memiliki makna dan tujuan dari kehidupannya.

Tingkat kesuksesan individu dalam mengatasi dan bertahan dalam situasi mereka tergantung pada pola-pola faktor resiko dan faktor protektif di lingkungan sosial individu, serta pada kekuatan dan kemampuan internal individu. Kerentanan meningkat ketika seorang individu menghadapi berbagai resiko dalam kehidupannya. Faktor protektif lebih penting dibandingkan dengan faktor resiko (Knight dalam Geldard, 2012) dan resiliensi akan meningkat ketika individu memiliki lebih banyak faktor protektif dibandingkan faktor resiko (http://www.cpwg.net). Penelitian telah menunjukkan secara konsisten bahwa terlepas dari faktor resiko yang memapari individu, faktor protektif internal dan eksternal dapat mengurangi dampak dari faktor resiko yang menerpa individu, seperti teman yang mendukung dan memiliki kemampuan yang baik dalam mencari pertolongan (Knight dalam Geldard, 2012).

Kemampuan resiliensi pada setiap remaja tentu berbeda-beda dan hal tersebut dipengaruhi oleh banyak faktor yang memaparinya. Terdapat berbagai macam dinamika psikologis dan pola resiliensi yang terjadi didalam tubuh remaja korban kekerasan yang tidak terlihat secara kasat mata. Oleh sebab itu, peneliti akan melakukan penelitian berkaitan dengan bagaimana dimanika resiliensi remaja yang pernah mengalami kekerasan orang tua dengan memperhatikan aspek, dampak kekerasan, serta faktor apa saja yang mempengaruhi resiliensi pada remaja korban kekerasan orang tua.

\section{METODE PENELITIAN}

Peneliti menggunakan jenis penelitian kualitatif dengan pendekatan fenomenologi dan pengumpulan data dilakukan menggunakan teknik wawancara serta observasi. Subjek dalam penelitian ini berjumlah 3 orang dengan kriteria remaja yang berusia 13-19 tahun, laki-laki atau perempuan, pernah mengalami kekerasan oleh orang tua, dan bersedia menjadi informan penelitian. 
Data yang dikumpulkan berupa profil umum informan, dampak-dampak yang terjadi akibat kekerasan, faktor-faktor pembentuk resiliensi, dan dinamika resiliensi informan.

\section{HASIL DAN PEMBAHASAN}

\section{Gambaran profil subjek}

Informan dalam penelitian ini berjumlah 3 orang dengan banyak perbedaan dari sisi usia, jenis kelamin, tingkat pendidikan, dan latar belakang keluarga. Nama samaran dari masingmasing informan yaitu informan Ana, Bento, dan Rima.

\begin{tabular}{|l|l|l|l|}
\hline Keterangan & Subjek Ana & Subjek Bento & Subjek Rima \\
\hline Usia & 15 tahun & 18 tahun & 19 tahun \\
\hline Jenis kelamin & Perempuan & Laki-laki & Perempuan \\
\hline Pendidikan & Putus sekolah & Kelas X SMA & S1 semester 1 \\
\hline anak ke- & 3 dari 5 bersaudara & 2 dari 2 bersaudara & 1 dari 2 bersaudara \\
\hline Alamat Asli & Yogyakarta & Yogyakarta & Kalimantan \\
\hline Alamat saat ini & Yogyakarta & Yogyakarta & Yogyakarta \\
\hline Pelaku kekerasan & Ibu tiri & Bapak kandung & Ibu kandung \\
\hline
\end{tabular}

Informan Ana merupakan anak ketiga dari lima bersaudara, dan keempat saudara informan yang lain merupakan saudara tiri informan dengan dua orang dari ibu tiri sebelum ibu informan dan dua orang lain dari ibu tiri informan saat ini. Informan Ana merupakan asli keturunan Jawa dan saat ini tinggal di Yogyakarta. Ibu kandung informan Ana meninggal saat informan berusia 1 bulan dan sejak saat itu informan tinggal bersama neneknya. Sejak ibu kandung informan Ana meninggal, informan tidak mendapatkan kasih sayang dari orang tuanya, termasuk kasih sayang dari bapak kandungnya.

Tidak lama setelah nenek informan meningal, bapak informan Ana kembali menikah dalam rangka nikah masal.
Informan Ana mengatakan bahwa informan tidak mengetahui sama sekali tentang rencana pernikahan bapaknya. Ketika informan Ana memiliki ibu tiri yang baru, informan Ana tinggal bersama ibu tiri dan bapaknya selama 4 tahun. Pada awal pernikahannya, ibu tiri Ana bersikap baik terhadap Ana dan lama kelamaan sikap ibu tiri Ana menjadi berubah terhadap Ana semenjak ibu tiri Ana hamil. Selain itu, ibu tiri Ana juga mengalami masalah penyesuaian dengan keberadaan anak dari istri yang sebelumnya. Hal tersebut menyebabkan ibu tiri sering melakukan pelampiasan dan memanfaatkan ketidakberdayan dari anak tirinya dan melakukan tindak kekerasan. Ibu tiri informan Ana berusaha agar bapak 
kandung Ana hanya sayang pada ibu tiri dan anaknya saja. Oleh sebab itu, ibu tiri informan Ana menggunakan dukun agar keinginan tersebut bisa terwujud dan informan Ana mulai diabaikan oleh bapak kandungnya.

Hal serupa dan sedikit berbeda juga dialami oleh informan Bento. Informan Bento merupakan anak kedua dari dua bersaudara. Informan Bento merupakan keturunan asli Jawa, tinggal di Yogyakarta, dan sempat menetap di Kalimantan. Ketika keluarga dari informan berpindah tempat tinggal dari Yogyakarta ke Kalimantan, terjadi banyak sekali perubahan sikap dari bapak informan seperti sering marah dan melakukan tindak kekerasan. Hal tersebut disebabkan oleh banyak sekali permasalahan yang dialami oleh bapak informan semenjak masih di Yogyakarta maupun setelah pindah ke Kalimantan, seperti adanya PHK, konflik dalam pembagian warisan, faktor ekonomi, dan faktor yang kurang mendukung dalam proses penyesuaian diri selama berada dan bekerja di Kalimantan. Menurut Suharto (dalam Huraerah, 2012), beberapa faktor yang menyebabkan anak mengalami kekerasan diantaranya yaitu, kondisi sosial-ekonomi rendah, seperti kemiskinan, orang tua pengangguran, serta kondisi lingkungan sosial yang tidak mendukung seperti kurang adanya penerimaan di tempat tinggal yang baru dan pandangan terhadap nilai anak yang begitu rendah.
Hal tersebut bisa menjelaskan penyebab dari tindak kekerasan yang dilakukan oleh bapak informan Bento.

Permasalahan mengenai penyesuaian dan kurang adanya kedekatan antara orang tua dan anak juga dialami oleh keluarga informan Rima. Informan Rima merupakan anak pertama dari dua bersaudara dengan adik kandung laki-laki. informan merupakan asli keturunan Kalimantan dan saat ini sedang berkuliah di Yogyakarta. Semasa kecil sejak ibu informan melahirkan adik informan, informan Rima dititipkan untuk tinggal di rumah neneknya selama kurang lebih 5 tahun. Hal yang dilakukan oleh ibunya tersebut membuat informan Rima merasa diabaikan dan informan tidak memperoleh kasih sayang dari ibunya. Menurut Chen (dalam Lestari, 2012), kualitas hubungan orang-tua dan anak merefleksikan tingkatan dalam hal kehangatan, rasa aman, kepercayaan, afeksi positif dan ketanggapan dalam hubungan. Kehangatan menjadi komponen dasar dalam hubungan orang tua anak yang membuat anak merasa dicintai dan mengembangkan rasa kepercayaan diri.

Kurang adanya kedekatan dan tidak adanya hubungan yang positif antara orang tua dan anak sering diekspresikan melalui tindak kekerasan dan pengabaian yang dilakukan oleh orang tua. Pelaku kekerasan yang dalam hal ini orang tua sering melakukan tindak kekerasan 
berupa kekerasan secara fisik, psikologis, dan sosial. Pada informan Ana, informan sering dipukul, digunduli, ditendang, diancam, dan diabaikan dalam hal nutrisi serta tidak diberikan tempat tinggal yang layak. Pada informan Bento, informan sering dipukul, dimarahi, dikurung di kamar mandi, dibiarkan kelaparan, serta dipermalukan di depan teman-teman informan. Pada informan Rima, informan pernah ditendang, dibentak, dijambak, diberikan perilaku tidak adil serta pengabaian dari ibunya.

Menurut Suyanto (2013), tindakan kekerasan atau pelanggaran terhadap hak individu dapat terwujud diantaranya dalam bentuk kekerasan fisik dan kekerasan psikis. Kekerasan fisik berupa tindak pemukulan yang menyebabkan luka secara fisik dan perubahan pada kondisi psikomotorik. Kekerasan psikis dapat berupa penggunaan kata-kata kasar, mempermalukan di depan umum, memaki, dan melontarkan ancaman dengan kata-kata. Hal tersebut sesuai dengan yang dialami oleh ketiga informan yaitu adanya tindak kekerasan berupa pelukaan secara fisik dan psikis. Berdasarkan pendapat dari Fatimah (1992) (dalam Huraerah, 2012), beberapa penyebab terjadinya kekerasan yaitu faktor ekonomi, kekecewaan terhadap kondisi kehidupan, masalah keluarga, dan faktor perceraian.

Tindak kekerasan yang dialami oleh informan tentu tidak terlepas dari berbagai kondisi yang menjadi faktor penyebab munculnya tindak kekerasan tersebut, seperti masaah ekonomi, masalah penyesuaian diri dan stress serta perubahan kondisi lingkungan yang terjadi secara tiba-tiba. Individu yang menjadi korban kekerasan di dalam rumah merupakan individu yang pada dasarnya kurang memiliki kekuatan yaitu anak dan kekerasan biasanya dilakukan oleh individu yang lebih berdaya dalam hal kekuatan yaitu orang tua. Kekuatan yang dimiliki tersebut dipergunakan secara tidak adil sehingga muncullah potensi untuk menyakiti anak yang memiliki ketidakerdayaan. Akibatnya muncullah berbagai dampak yang terjadi berkaitan dengan tumbuh kembang anak dari segi fisik, psikologis, dan perilaku yang mengalami gangguan jika individu tidak memperoleh faktor pendukung yang bisa membuatnya bangkit dari keterpurukan akibat perlakua tidak menyenangkan yang diterimanya.

\section{Dampak-Dampak Kekerasan \\ Dampak Fisik}

Dampak dari kekerasan secara fisik yang dialami oleh informan korban kekerasan seperti, informan Ana yang mengalami sakit, gangguan fungsi kognisi \& psikomotorik, tubuh yang kurus, dan daya tahan tubuh yang lemah. Informan Bento mengalami sakit secara fisik serta pernah kelaparan karena tidak diberikan 
makanan. Informan Rima mengalami luka secara fisik, lebam, pusing, dan pingsan.

\section{Dampak Psikologis}

Dampak secara psikologis membutuhkan pemulihan lebih lama dan bisa menimbulkan dampak jangka panjang (http://www.kpai.go). Berdasarkan dari hasil wawancara dan observasi yang dilakukan terhadap informan dalam penelitian ini, masih terdapat beberapa dampak yang masih melekat pada diri informan sampai saat ini. Meskipun informan sudah melewati banyak perkembangan kehidupan sampai saat ini, terkadang dampak negatif sebagai akibat dari tindak kekerasan yang dialami di masa lalu masih dirasakan. Terdapat beberapa kesamaan dampak psikologis pada ketiga informan seperti adanya rasa takut dan trauma terhadap pelaku maupun terhadap bentuk kekerasan, pemurung, pendiam, sakit hati, marah, malu, dan gugup. Persamaan dampak pada informan Rima \& Bento yaitu pernah ada keinginan untuk membalas perbuatan orang yang sudah melakukan kekerasan terhadap informan. Pada informan Bento, terdapat indikasi dendam terhadap pelaku kekerasan dan informan tumbuh menjadi orang yang pemarah serta harga diri rendah.

Dampak lain yang terlihat pada informan Ana yaitu informan sering memendam perasaan, menangis sendiri, pemalu, penakut. Dampak pada diri ketiga informan yang masih terlihat sampai saat ini seperti, masih ada rasa marah \& sakit hati, mudah sedih \& menangis, teringat dengan kejadian kekerasan, dan bertindak sesuai dengan suasana hati. Selain itu, Informan Rima sering mengalami pikiran tidak realistik dan membayangkan suatu hal yang buruk akan terjadi. Informan juga menjadi takut dengan gelap dan mengalami kesulitan tidur di malam hari.

\section{Dampak Perilaku}

Dampak secara perilaku yang dialami oleh informan penelitian dan memiliki kesamaan diantara ketiganya yaitu, pergi dari rumah, menghindari pelaku kekerasan, serta menjauh dari kondisi yang membuat tertekan. Pada informan Rima, informan lebih memilih diam sebagai bentuk dari rasa marah. Selain itu, informan Rima juga lebih baik berada di luar rumah, daripada harus lama-lama berada di rumah. Informan Ana menjadi berperilaku tidak seperti anak pada umumnya, tidak mendapatkan makanan yang layak sehingga informan Ana sering mencari makan dari makanan sisa. Informan Bento menjadi individu yang agresif dan mudah marah.

\section{Dampak Sosial}

Dampak secara sosial yang terjadi pada ketiga informan penelitian yaitu hubungan pertemanan informan menjadi terganggu karena tindak kekerasan dan dipermalukan di depan umum. Akibatnya, 
informan menjadi diejek oleh temanteman, informan menarik diri, menyendiri, dan tidak berminat dalam pergaulan.

\section{Dampak Akademis}

Dampak secara akademis yang terjadi pada individu korban kekerasan yaitu nilai menurun, kurang ada minat dalam sekolah, kurang adanya kepercayaan diri dalam belajar, dan putus sekolah. Informan Ana putus sekolah karena takut untuk pulang ke rumah. Informan Bento memperoleh nilai yang rendah pada mata pelajaran dan kekerasan yang dilakukan oleh bapak informan membuat informan menjadi malas untuk sekolah. Pada informan Rima, informan sering mengalami tekanan dalam bidang akademis seperti tidak adanya penghargaan dari ibunya dan ibunya sering membanding-bandingkan informan dengan anak-anak yang lain yang lebih baik dalam hal akademis. Namun informan Rima memiliki kepribadian yang kuat dan percaya diri sehingga informan bisa mengubah tekanan sebagai media untuk terus menunjukkan bahwa informan memiliki kemampuan yang bisa dibanggakan.

\section{Faktor-Faktor Penyebab Kekerasan}

Terdapat dua faktor yang mempengaruhi resiliensi dalam diri individu yaitu faktor protektif dan faktor resiko (Barankin \& Khanlou dalam Karina, 2014), yaitu:

\section{Faktor Protektif}

a. Internal

Faktor protektif yang dimiliki oleh ketiga informan penelitian yaitu adanya penilaian yang positif terhadap kehidupan saat ini. Ketiga informan saat ini sudah tinggal jauh dari pelaku kekerasan yang membuat informan tertekan. Oleh sebab itu, ketiga informan merasa bahwa saat ini kehidupan informan terasa lebih baik, lebih tenang, lebih aman, dan bahagia. Informan Rima memiliki minat dan keyakinan dengan kemampuannya dalam bidang akademis. Informan Rima juga memilih untuk menjalani sebanyak mungkin kegiatan agar pikiran terhadap hal-hal yang menyakitkan bisa teralihkan. Rima juga memiliki locus of control internal yang membuat informan tidak sepenuhnya melipahkan kesalahan masa lalu kepada ibunya. Informan Bento memiliki pikiran positif dan keyakinan bahwa merupakan hal yang wajar ketika salah dalam belajar. Hal tersebut tertanam didalam diri informan Bento dan membuat informan menjadi bersemangat untuk kembali bersekolah terlepas dari kondisi masa lalu. Informan Bento menjadi semakin semangat untuk bersekolah ditambah ketika adanya dukungan dari kakak informan. 
b. Eksternal

Adanya dukungan sosial dari anggota keluarga seperti kakak, tante, dan nenek. Selain itu terdapat pula dukungan dari pihak lain diluar anggota keluarga seperti pihak panti asuhan, ibu \& saudara angkat, serta teman-teman. Kegiatan sehari-hari yang dilakukan oleh informan juga berpengaruh terhadap terbentuknya resiliensi. Pada informan Rima dan Bento, kedua informan ini memiliki minat dan bakat dalam bidang-bidang tertentu seperti olahraga dan menggambar, serta minat dalam belajar. Informan Ana diajarkan oleh ibu angkatnya untuk melakukan pekerjaan rumah seperti memasak dan membersihkan rumah.

Informan Ana juga melakukan kegiatan rutin keagaaman di dalam lingkungan panti seperti sholat, tadarrus, mendengar ceramah keagamaan, dan menghafal Al-Qur'an. Kegiatan rutin, minat, dan bakat yang dimiliki informan bisa memnbentuk resiliensi pada diri informan.

\section{Faktor Resiko}

a. Individu

Belum adanya pemaafan terhadap pelaku kekerasan, masih menyimpan rasa marah, serta pesimis terhadap hubungan yang baik diantara anggota keluarga merupakan beberapa faktor resiko yang berasal dari internal informan. Bayangan dan ingatan masa lalu yang masih muncul di kehidupan ketiga informan saat ini juga bisa menjadi faktor yang bisa menjadi penghambat terbentuknya resiliensi pada diri informan dan membuat informan menjadi mudah sedih. Meskipun begitu, masing-masing dari informan mempunyai cara-cara tersendiri agar bisa bangkit dari peristiwa yang menyakitkan.

b. Keluarga

Kondisi keluarga yang kurang harmonis dan pelaku kekerasan yang merupakan anggota keluarga dekat informan adalah beberapa diantara banyak faktor resiko yang bisa meningkatkan dampak negatif pada diri informan.

Tindak kekerasan yang dialami oleh Ana dilakukan oleh ibu tiri Ana dan Ana tidak pernah mendapatkan pembelaan sedikitpun dari bapak kandung Ana.

c. Masyarakat

Kondisi yang ada di masyarakat juga bisa mempengaruhi tingkat resiliensi pada diri individu. Pada informan Ana, tidak adanya pertolongan dari masyarakat ketika informan mengalami tindak kekerasan bisa menjadi salah satu faktor yang meningkatkan dampak negatif pada diri informan. Masyarakat memiliki ketakutan untuk menolong informan karena ibu tiri informan yang selalu 
mengancam. Bapak dukuh di tempat informan tinggal juga tidak bisa menolong informan karena takut dengan ancaman yang dilontarkan oleh ibu tiri informan. Informan Rima sering merasa bahwa ibunya tidak pernah sayang kepada dirinya. Masyarakat juga mengatakan bahwa ibu informan memang lebih menyayangi anak laki-laki dibandingkan dengan anak perempuan, dan hal tersebut menimbulkan kesedihan pada diri informan.

\section{Dinamika Resiliensi}

Menurut Yusuf (2014), keluarga merupakan lingkungan primer yang penting bagi setiap individu yaitu keluarga merupakan hubungan manusia yang paling intensif dan paling awal terjadi. Namun banyaknya peristiwa kekerasan yang dilakukan oleh orang tua, membuat individu merasa tidak aman dan tidak terlindungi. Kekerasan yang dialami oleh informan dalam penelitian ini disebabkan oleh banyak hal yaitu adanya perubahan kondisi kehidupan dan kurang adanya kemampuan dalam penyesuaian, faktor ekonomi, konflik keluarga, konflik sosial, dan kesalahan-kesalahan kecil yang dilakukan oleh informan. Menurut Fatimah (dalam Huraerah, 2012), terdapat beberapa penyebab terjadinya kekerasan yaitu faktor ekonomi, dan masalah keluarga, konflik keluarga. Selain itu kondisi individu dan kondisi sosial juga berpengaruh terhadap terjadinya kekerasan pada individu (Suharto dalam Huraerah, 2012). Informan yang masih kecil dan tidak berdaya menjadi alasan bagi orang tua untuk menunjukkan dirinya lebih kuat dan menyalahgunakan kekuatan tersebut. Menurut Barker dalam Huraerah (2012), kekerasan dalam keluarga terjadi karena adanya penyalahgunaan kekuatan oleh yang kuat terhadap yang lemah dan anak diposisikan sebagai orang yang tidak berdaya dan dilemahkan.

Adanya kondisi-kondisi yang terjadi didalam keluarga bisa menyebabkan pelampiasan emosi yang dilakukan oleh orang tua terhadap anak didalam keluarga. Bentuk-bentuk kekerasan yang dilakukan tersebut bisa berupa kekerasan fisik \& psikologis. Informan mengalami kekerasan seperti dipukul, dimaki, diabaikan, diancam, dan dipermalukan. Menurut Suyanto (2013), kekerasan terhadap individu bisa terjadi dalam beberapa bentuk yaitu kekerasan secara fisik dan psikologis serta dampaknya bisa berakibat jangka panjang sehingga dampak secara psikologis menjadi sulit disembuhkan. Menurut Komisi Perlindungan Anak Indonesia, dampak psikologis dari kekerasan membutuhkan pemulihan yang lebih lama dan bisa menimbulkan dampak jangka panjang (http://www.kpai.go). 
Dampak-dampak yang terjadi pada diri ketiga informan korban kekerasan bisa berupa dampak secara fisik, psikologis, perilaku, sosial, dan akademis. Informan mengalami luka secara fisik, pusing, pingsan, lebam, dan gangguan pada psikomotorik. Informan juga mengalami dampak secara psikologis berupa rasa sedih \& mudah menangis, takut, pendiam, sakit hati, tidak tenang, marah \& indikasi dendam, kecewa, harga diri rendah, malu, serta terbayang-bayang dengan kejadian kekerasan. Selain itu, kondisi sosial pertemanan dan kondisi akademik informan juga menjadi terganggu. Informan tidak bisa berteman dengan baik, dan proses sekolah serta belajar individu juga terhambat.

Dampak-dampak negatif tentu muncul sebagai akibat dari tindak kekerasan dan perilaku tidak menyenangkan yang dialami. Meskipun begitu, setiap individu memiliki potensi untuk bisa berubah dan bangkit dari masa lalu yang menyakitkan. Salah satu aspek psikososial yang penting dimiliki individu agar bisa bangkit dari masa lalu yang menyakitkan yaitu perkembangan resiliensi. Menurut Grothberg (dalam Karina, 2014), resiliensi adalah kapasitas individu untuk menghadapi, mengatasi, bahkan menjadi lebih kuat dalam tekanan hidup yang sulit. Tekanan hidup yang dialami oleh informan berkaitan dengan adversitas berupa pengalaman buruk dan kejadian yang tidak menyenangkan yang pernah terjadi di masa lalu.

Informan Ana memiliki keinginan untuk meminta bantuan dan pertolongan dari orang lain. Menurut Knight dalam Geldard (2012), kemampuan yang baik dalam mencari pertolongan merupakan salah satu faktor indvidu untuk bisa bangkit dari keterpurukan. Individu yang merasa tidak aman akan cenderung mencari lingkungan atau tempat yang bisa memberikan rasa aman pada diri individu. Mencari pertolongan merupakan salah satu faktor yang dilakukan oleh informan Ana agar dirinya bisa memperoleh rasa aman dalam hidup. Sejak kepindahan informan Ana ke rumah ibu angkatnya pada saat informan menginjak bangku kelas 5 SD, informan menjadi banyak memperoleh dukungan dan informan juga diajari untuk melakukan hal-hal yang berkaitan dengan pekerjaan rumah tangga. Saat ini informan tinggal di panti asuhan dengan alasan agar informan bisa terhindar dari ancaman yang masih sering dilakukan oleh ibu tirinya.

Informan Bento mulai berpikir untuk menjalani kehidupan yang lebih baik sejak adanya dukungan dan tawaran dari kakak kandung informan agar informan kembali bersekolah di Yogyakarta. Dukungan terus-menerus yang diberikan oleh kakak informan membuat informan sadar hingga akhirnya informan memutuskan untuk kembali bersekolah. Hal serupa juga dialami oleh 
informan Rima. Informan Rima memiliki karakter yang kuat dalam dirinya sehingga segala bentuk kekerasan dan pengabaian yang dilakukan oleh ibu informan ketika informan SMP, menjadi salah satu media untuk informan Rima agar informan bisa bangkit dan menunjukkan bahwa informan bisa menjadi individu yang dibanggakan.

Resiliensi yang terwujud pada diri individu dipengaruhi oleh beberapa faktor yaitu faktor protektif dan faktor resiko. Tingkat kesuksesan individu dalam mengatasi dan bertahan dalam situasi kehidupan bergantung pada pola-pola faktor resiko dan faktor protektif dalam lingkungan individu. Resiliensi akan meningkat ketika individu memiliki lebih banyak faktor protektif dibandingkan dengan faktor resiko (http://www.cpwg.net). Faktor-faktor protektif yang terbentuk pada diri ketiga informan berupa karakteristik internal dari informan yang kuat dan memiliki kemauan untuk berubah, dukungan sosial yang diperoleh, memiliki minat \& bakat, suasana kehidupan yang lebih baik \& nyaman, serta adanya kegiatan \& rutinitas sehari-hari yang bermanfaat. Selain itu, ketiga informan penelitian memiliki penilaian yang positif terhadap kehidupan saat ini. Ketiga informan saat ini sudah tinggal jauh dari pelaku kekerasan yang membuat informan tertekan. Oleh sebab itu, ketiga informan merasa bahwa saat ini kehidupan informan terasa lebih baik, lebih tenang, lebih aman, dan bahagia. Faktor resiko yang dimiliki oleh ketiga informan berupa kurang adanya kemauan untuk menjalin hubungan yang baik dengan pelaku kekerasan, belum adanya pemaafan terhadap pelaku kekerasan, serta masih ada bayang-bayang dan ketergantungan terhadap masa lalu yang menyakitkan.

Berbagai faktor yang dimiliki oleh informan tersebut bisa mempengaruhi terbentuknya resiliensi pada diri informan seperti informan memiliki regulasi emosi yang baik. Informan memiliki kemampuan untuk menjadi pribadi yang tidak bergantung pada orang lain dalam memilih kehidupannya dan memikirkan pentingnya sekolah demi masa depan yang lebih baik. Informan memiliki kemampuan untuk bisa menjalin hubungan yang baik dengan orang lain serta memiliki kemampuan untuk mengubah kesedihan menjadi media untuk bisa bangkit dan mandiri, seperti adanya keinginan untuk membuktikan bahwa informan juga memiliki kemampuan untuk menjadi seseorang yang bisa dibanggakan.

Adanya kontrol impuls juga dimiliki oleh ketiga informan. Informan seperti remaja pada umumnya tentu memiliki sesuatu keinginan atau dorongan yang ingin dipenuhi seperti kebutuhan secara fisik, psikologis, dan sosial (Willis, 2008). Namun terdapat hal-hal yang harus dikontrol oleh individu karena tidak 
semua kebutuhan bisa dipenuhi secara baik. Ketiga informan cenderung bisa untuk mengendalikan dorongan-dorongan yang dimiliki, seperti informan memiliki pemahaman yang baik terhadap kehidupan yang dijalani dan lebih memilih untuk hidup sederhana dan tidak menuruti keinginan dan impuls.

Informan Bento mengatakan bahwa informan merasa kasihan terhadap kakak kandungnya yang sudah berusaha untuk menyekolahkan informan dengan cara bekerja. Oleh sebab itu, informan Bento mengerti dan tidak menuntut banyak untuk meminta sesuatu dari kakaknya asalkan informan bisa terus bersekolah. Hal serupa juga dimiliki oleh informan Rima yaitu informan memilih untuk hidup sederhana serta selalu memiliki rasa syukur atas apa yang diperoleh. Informan juga berusaha mandiri dengan cara bekerja untuk bisa terus berkuliah.

Informan Rima memiliki kemampuan untuk mengalihkan perhatian dari hal-hal yang menyakitkan seperti banyak mencari teman dan melakukan kegiatan lain di luar rumah. Informan Rima memiliki pengendalian diri yang baik terhadap tekanan dan bisa mengubah tekanan sebagai media untuk bangkit. Hal tersebut ditunjukkan oleh informan Rima ketika berusaha untuk mendapatkan beasiswa dan bersekolah atas keinginannya agar bisa menjadi orang yang lebih baik. Perasaan optimis terhadap kehidupan dan masa depan yang lebih baik dimiliki oleh informan Bento dan Rima. Belajar dan berusaha merupakan cara agar informan bisa sukses dan meraih cita-cita di masa depan. Kedua informan memiliki harapan dan cita-cita yang ingin informan wujudkan di masa depan. Informan Rima melakukan banyak hal agar bisa terus bersekolah seperti dengan cara mencari beasiswa dan bekerja sambil berkuliah.

Informan Rima juga memiliki efikasi yang baik dalam dirinya. Informan tidak berputus asa atas peristiwa pahit yang pernah dialami di masa lalu. Informan bisa mengubahnya menjadi suatu media untuk bangkit dan membuat informan berusaha menjadi seseorang yang lebih baik lagi. Salah satu hal yang membentuk resiliensi pada diri informan Rima yaitu adanya kepercayaan terhadap kemampuan diri sendiri agar bisa sukses dalam belajar dan meraih cita-cita di masa depan. Hal tersebut diwujudkan dalam bentuk kepercayaan diri dalam kemampuannya di bidang akademik dan sosial. Informan melanjutkan sekolah dengan beasiswa dan bekerja, serta informan lebih memilih untuk mencari teman yang banyak dan menjalin relasi daripada harus terpuruk dalam penderitaan. Menurut Reivich \& Shatte (2002), efikasi diri merupakan salah satu aspek dari resiliensi dan terbentuk pada diri informan.

Informan Bento sudah bersedia untuk bersekolah kembali serta memiliki kesadaran dan harapan untuk 
memperoleh masa depan dan kehidupan yang lebih baik. Informan Bento juga memiliki cita-cita di masa depannya dan informan menganggap belajar merupakan salah satu cara agar informan bisa mendapatkan masa depan yang lebih baik. Informan Ana juga memiliki kemauan untuk bersekolah kembali dan memiliki penilaian yang baik terhadap kehidupannya saat ini, meskipun harapan terhadap sekolah masih kecil. Informan Rima memiliki pikiran yang realistis, optimis, dan memiliki rasa syukur atas kehidupannya. Informan memiliki penilaian yang baik terhadap kehidupannya yang sekarang. Informan memiliki kesadaran dan belajar dari setiap peristiwa yang dialami, memiliki harapanharapan untuk hidup di masa depan, serta bisa menemukan makna dari hidup yang informan jalani saat ini. Selain itu, informan Bento dan informan Rima memiliki bakat dan minat dalam beberapa bidang serta berusaha untuk terus menggali potensi yang dimiliki.

Menurut keterangan dari kakak kandung informan Bento, informan sudah memiliki banyak perubahan diantaranya informan sudah bisa untuk diajak berbicara dan merespon dengan baik terhadap pembicaraan dengan orang lain. Selain itu, informan Rima dan Ana juga memiliki perubahan yang sama dan ke arah yang lebih baik. Informan Bento juga memiliki kemampuan untuk melepaskan diri dari kehidupan masa lalu yang sulit.
Informan berkata bahwa lebih baik tidak berusaha untuk mencari tau hal-hal yang menyakitkan untuk diketahui dan hanya berfokus pada masa depan.

Informan dalam penelitian ini memiliki potensi resiliensi dan bisa bangkit dari masa lalu yang menyakitkan. Berbagai upaya tersebut tidak terlepas dari aspek eksternal maupun internal yang dimiliki oleh individu. Individu yang memiliki keinginan yang kuat dari dalam diri, bisa bangkit dan berubah dalam kehidupannya dan hal tersebut juga diimbangi oleh faktor eksternal yang dimiliki seperti adanya dukungan sosial dan kondisi kehidupan saat ini yang lebih nyaman dan jauh dari pelaku kekerasan. Informan cenderung memiliki penilaian yang baik terhadap kehidupannya saat ini dan optimis bisa memperoleh kehidupan yang lebih baik terlepas dari masa lalu yang menyakitkan.

\section{KESIMPULAN DAN SARAN}

Berdasarkan hasil dan pembahasan yang sudah dijelaskan pada penelitian mengenai dinamika resiliensi remaja yang pernah mengalami kerasan orang tua, maka dapat disimpulkan bahwa:

1. Remaja memiliki resiliensi yang terwujud dalam beberapa aspek yaitu remaja memiliki penilaian yang baik terhadap kehidupan saat ini, adanya perubahan fisik yang lebih baik, memiliki harapan \& cita-cita, optimis, memiliki kemampuan dalam 
memecahkan masalah, memiliki impuls kontrol yang baik, memiliki efikasi diri, realistis terhadap hal-hal baik yang bisa dilakukan, dan memiliki rasa syukur. Selain itu, remaja memiliki kemampuan yang lebih baik dalam berkomunikasi dan memiliki kemampuan melepaskan diri dari masa lalu yang menyakitkan.

2. Dampak yang terjadi akibat dari kekerasan di masa yang lalu sudah mulai berkurang saat ini. Remaja sudah mulai dan bisa menjalani kehidupan yang lebih baik, berusaha mandiri, dan bertanggung jawab terhadap kehidupannya sendiri.

3. Remaja memiliki faktor pendukung di dalam kehidupannya, antara lain remaja memiliki karakteristik individu yang kuat, dukungan dari orang lain, adanya kegiatan yang bermanfaat, dan beberapa minat serta bakat yang dimiliki. Selain itu, suasana kehidupan yang berbeda dan lebih baik serta adanya jarak dari pelaku kekerasan juga menjadi faktor pendukung bagi informan untuk bisa resilien dalam kehidupannya.

4. Remaja juga memiliki faktor penghambat di dalam dirinya yaitu, kurang adanya kemauan dan kemampuan untuk menjalin hubungan yang baik dengan pelaku kekerasan, belum adanya pemaafan, dan masih ada rasa ketergantungan terhadap bayang-bayang masa lalu yang menyakitkan dan berdampak terhadap kehidupan saat ini.

Saran yang dimuat di dalam penelitian ini yaitu:

1. Bagi Keluarga Informan

Diharapkan dengan adanya penelitian ini, pihak keluarga bisa lebih memahami dan lebih peka terhadap apapun yang terjadi di dalam keluarga yang berdampak terhadap kehidupan anggota keluarga lainnya. Semoga pihak keluarga dan orangorang terdekat bisa memberikan dukungan yang bermafaat dalam proses remaja untuk bisa bangkit dari pengalaman kehidupan yang kurang menyenangkan.

2. Bagi Teman Terdekat Informan Diharapkan penelitian ini bisa membawa dampak baik, hubungan yang lebih erat, dan saling mendukung dalam kondisi sosial pertemanan informan yang bersangkutan.

3. Bagi Pengasuh Panti

Diharapkan penelitian ini bisa membawa dampak baik serta hubungan yang lebih erat antara peneliti, pihak panti, dan informan itu sendiri. Semoga pihak panti lebih bisa memahami kondisi dari anak yang mengalami kekerasan maupun anakanak lain yang memiliki permasalahan yang berbeda dan membutuhkan dukungan. 
4. Bagi Informan

Diharapkan dalam proses penelitian hingga tahap akhir penulisan penelitian ini bisa bermanfaat dan membawa dampak baik dalam hubungan pertemanan dan perubahan kondisi sosial psikologis informan. Semoga keberadaan peneliti bisa memberikan manfaat bagi informan maupun bagi peneliti sendiri.

5. Bagi peneliti sendiri

Diharapkan penelitian ini bisa menjadi media untuk belajar agar peneliti bisa menjadi peneliti yang lebih baik di masa depan. Selain itu diharapakan peneliti bisa mengembangkan fenomenafenomena lain kedalam penelitian selanjutnya dan belajar dari setiap keterbatasan yang ada.

6. Bagi penelitian selanjutnya

Semoga penelitian ini bisa menjadi acuan dalam rangka penelitian lanjutan di masa yang akan datang. Diharapkan peneliti lainnya bisa melakukan penelitian yang lebih mendalam mengenai tema yang sama dan lebih spesifik sehingga bisa melengkapi penelitian yang sudah ada.

\section{DAFTAR PUSTAKA}

Child Protecton Working Group, Standar minimimum perlindungan anak dalam aksi kemanusiaan, http://www.cpwg.net yang diunduh pada 16 Maret 2016 pada pukul 14.10 WIB

Desmita. 2009. Psikologi Perkembangan Peserta Didik. Bandung: Remaja Rosdakarya Offset.

Geldard, Kathryn. 2012. Konseling Ramaja Intervensi Praktis Bagi Remaja Beresiko. Yogyakarta: Pustaka Pelajar http://www.jogja.tribunnews.com yang diunduh pada tanggal 10 September 2016 pada pukul 13.45 WIB

http://www.kpai.go yang diunduh pada tanggal 10 September 2016 pada pukul 14.00 WIB

Huraerah, Abu. 2012. Kekerasan Terhadap Anak. Bandung: Nusa Cendekia

Karina, Canggih. 2014. Resiliensi Remaja yang Memiliki Orang Tua Bercerai. Jurnal Online Psikologi. Vol.2, No.1, Hal 152-169

Lestari, Sri. 2012. Psikologi Keluarga Penanaman Nilai dan Penanganan Konflik Keluarga. Jakarta: Kencana Prenada Media Grup

Margaretha., Nuringtyas, Rahmaniar., \& Rachim, Rani. 2013. Trauma Kekerasan Masa Kanak dan Kekerasan dalam Relasi Intim. Makara Seri Sosial Humaniora. Vol 17, No 1 
Reivich \& Shatte. 2002. The Resilience Factors: 7 Keys to Finding Your Inner Strength and Overcoming Life's Hurdles

Suyanto, Bagong. 2013. Masalah Sosial Anak. Jakarta: Kencana Prenada Media Group

Willis, Sofyan.S. 2008. Remaja dan Masalahnya. Bandung: Penerbit Alfabeta

Mulia, Lamda, O., Elita, Veny, \& Wofers, Rismadefi. 2014. Hubungan Dukungan Sosial Teman Sebaya terhadap Tingkat Resiliensi Remaja di Panti Asuhan. JOM PSIK. Vol.1 No.2. Hal 1-9 